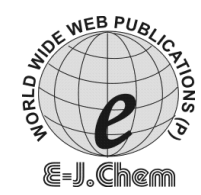

http://www.e-journals.net

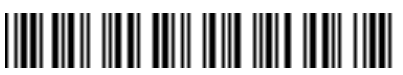

ISSN: 0973-4945; CODEN ECJHAO

E-Journal of Chemistry

Vol. 4, No. 3, pp. 302-306, July 2007

\title{
RP-HPLC Method for the Estimation of Nelfinavir Mesylate in Tablet Dosage Form
}

\author{
K. VANITHA PRAKASH, J. VENKATESWARA RAO* and N. APPALA RAJU \\ Department of Pharmaceutical Chemistry, \\ Sultan-Ul-Uloom College of Pharmacy, \\ Mount Pleasant, Road No. 3, Banjara Hills, Hyderabad-500 034.
}

jvrao1963@yahoo.co.in

Received 2 July 2006; Accepted 6 August 2006

\begin{abstract}
A reverse phase HPLC method is described for the determination of Nelfinavir Mesylate in tablet dosage form. Chromatography was carried on an ODS column using a mixture of acetonitrile and phosphate buffer $\mathrm{pH} 6$ $(90: 10 \mathrm{v} / \mathrm{v})$ as the mobile phase at a flow rate of $1.2 \mathrm{~mL} / \mathrm{min}$ with detection at $230 \mathrm{~nm}$. The retention time of the drug was $6.68 \mathrm{~min}$. The detector response was linear in the concentration of $1-20 \mathrm{mcg} / \mathrm{mL}$. The limit of detection and limit of quantification was 1.0 and $10.0 \mathrm{mcg} / \mathrm{mL}$ respectively. The percentage assay of Nelfinavir Mesylate was $99.77 \%$. The method was validated by determining its sensitivity, accuracy and precision. The proposed method is simple, fast, accurate and precise and hence can be applied for routine quality control of Nelfinavir Mesylate in bulk and tablet dosage form.
\end{abstract}

Keywords: Nelfinavir Mesylate, RP-HPLC, Estimation, and Tablets.

\section{Introduction}

Nelfinavir Mesylate ${ }^{1}$ is a novel HIV-1 protease inhibitor; with a chemical name $(3 \mathrm{~S}, 4 \mathrm{aS}$, 8aS)-N- (1,1-Dimethylethyl) decahydro-2- [(2R, 3R)-2-hydroxy-3- [(3-hydroxy-2-methyl benzoyl) amino]-4-(phenylthio) butyl]-3-isoquinolinecarboxamide methanesulfonate .It is an antiretroviral drug that acts by binding reversibly to HIV protease thereby preventing cleavage of the viral precursor polyproteins. It is official in Martindale ${ }^{2}$-The Extra pharmacopoeia. Literature survey reveals many Chromatographic methods ${ }^{3-10}$ for the determination of Nelfinavir in biological fluids and in combination with other antivirals and few Spectrophotometric methods ${ }^{11-14}$ only. No method so far has been reported for the estimation of Nelfinavir Mesylate from pharmaceutical dosage form. The present paper aims 
at reporting an isocratic RP-HPLC method for the estimation of Nelfinavir Mesylate in tablet dosage form.

\section{Experimental}

Nelfinavir Mesylate was obtained as a gift sample from Aurobindo Pharma Ltd, Hyderabad. Acetonitrile HPLC grade, sodium hydroxide AR grade, potassium hydrogen orthophosphate AR grade of Rankem ltd. Water HPLC grade of Milli-Q were used.

\section{Instrument}

High Performance Liquid Chromatograph, Waters Alliance separation module 2695, equipped with automatic injector with injection volume $100 \mu \mathrm{L}$, Ultra-violet Visible detector Waters 2487 Dual alpha absorbance detector with Empower software.

\section{Chromatographic conditions}

Chromatographic separations were achieved using a Inertsil ODS C18 (250X4.6 mm, $5 \mu)$ analytical column. The mobile phase consisting of acetonitrile and phosphate buffer $\mathrm{pH} 6$ $(90: 10 \mathrm{v} / \mathrm{v})$ was passed through $0.45 \mu \mathrm{m}$ membrane filter and degassed by ultrasonication. The flow rate was maintained at $1.2 \mathrm{~mL} / \mathrm{min}$ and the measurements were made at $230 \mathrm{~nm}$. The column and the HPLC system were kept in ambient temperature.

Preparation of Mobile phase: Phosphate buffer pH 6 was prepared by dissolving 1.36 gms of potassium hydrogen orthophosphate in $1000 \mathrm{~mL}$ of water and by adjusting the $\mathrm{pH}$ to 6 with 0.1 N Sodium Hydroxide.

Preparation of Standard Stock solution: Accurately weighed $50 \mathrm{mg}$ of Nelfinavir Mesylate standard was taken in $50 \mathrm{ml}$ volumetric flask. This was dissolved in $25 \mathrm{~mL}$ of mobile phase and sonicated for $5 \mathrm{mins}$, and then diluted to $50 \mathrm{~mL}$ with the mobile phase to get $1 \mathrm{mg} / \mathrm{mL}$ standard stock solution.

Working Standard solution: $5 \mathrm{~mL}$ of the above stock solution was taken in $50 \mathrm{ml}$ volumetric flask and thereafter made upto $50 \mathrm{~mL}$ with mobile phase to get a concentration of $100 \mu \mathrm{g} / \mathrm{mL}$.

Preparation of Sample solution: Twenty tablets (Nelfin, Genix Pharma) were weighed accurately and finely powdered. The powder equivalent to $100 \mathrm{mg}$ was taken in $100 \mathrm{~mL}$ volumetric flask. This was dissolved in $75 \mathrm{~mL}$ mobile phase and sonicated for 15 mins with internal shaking. Then the volume was finally made to $100 \mathrm{~mL}$. The above solution was centrifuged at $3000 \mathrm{rpm}$ for 5 mins to get a clear solution. Then pippetted out $5 \mathrm{~mL}$ of clear supernatant liquid into $50 \mathrm{~mL}$ volumetric flask and made up the volume with mobile phase to get a concentration of $100 \mu \mathrm{g} / \mathrm{mL}$.

Linearity: Several aliquots of standard stock solutions $(0.1,0.25,0.5,1.0,1.5$ and 2.0$) \mathrm{mL}$ $(1 \mathrm{~mL}=100 \mu \mathrm{g} / \mathrm{mL})$ of Nelfinavir Mesylate were taken in different $10 \mathrm{~mL}$ volumetric flask and diluted up to the mark with mobile phase. Evaluation was performed with Ultra-Violet Dual alpha absorbance detector at $230 \mathrm{~nm}$. Peak area was recorded for all the peaks and a Calibration graph was obtained by plotting peak area versus concentration of Nelfinavir Mesylate (Figure 2). The plot of peak area of each sample against respective concentration of Nelfinavir Mesylate was found to be linear in the range of $1.0-20.0 \mu \mathrm{g} / \mathrm{mL}$ with correlation coefficient of 0.9999 . Linear regression least square fit data obtained from the measurements are given in Table 1. The respective slope $(\mathrm{m})$, intercept (b), standard deviation and correlation coefficient are given in Table 1. 
Table 1. Linear Regression Data for Calibration curves.

\begin{tabular}{lc}
\hline Drug & Nelfinavir Mesylate \\
\hline Concentration range $(\mathrm{mcg} / \mathrm{mL})$ & $1-20$ \\
Slope $(\mathrm{m})$ & 9940.18 \\
Intercept $(\mathrm{b})$ & 6657.9 \\
Correlation coefficient & 0.9999 \\
Variance & 0.011 \\
\% RSD & 0.2 \\
\hline
\end{tabular}

Assay: $10 \mu \mathrm{L}$ of sample solution was injected into the injector of liquid chromatograph. The retention time was found to be 6.68 mins. The amount of drug present per tablet was calculated by comparing the peak area of the sample solution with that of the standard solution. The data are presented in Table 2.

Table 2. Results of HPLC assay and Recovery studies

\begin{tabular}{cccc}
\hline Sample & $\begin{array}{c}\text { Amount claim } \\
(\mathrm{mg} / \text { tablet })\end{array}$ & $\begin{array}{c}\text { Amount found } \\
(\mathrm{mg} / \text { tablet })\end{array}$ & \% Recovery* \\
\hline 1. & 625 & 618.5 & 99.65 \\
2. & 625 & 620.5 & 99.29 \\
3. & 625 & 626.3 & 100.27 \\
4. & 625 & 625.3 & 99.97 \\
5. & 625 & 627.5 & 100.45 \\
& & Mean $=623.6$ & Mean $=99.92$ \\
\hline
\end{tabular}

*Average of three different concentration levels.

Recovery Studies: Accuracy was determined by recovery studies of Nelfinavir Mesylate, known amount of standard was added to the preanalysed sample and subjected to the proposed HPLC analysis. Results of recovery study are shown in Table 2. The study was done at three different concentration levels.

\section{Results and Discussion}

As per the USP-XXIV system suitability tests were carried out on freshly prepared standard stock solution of Nelfinavir Mesylate. Parameters that were studied to evaluate the suitability of the system are given in Table 3 .

Table 3. Validation Summary

\begin{tabular}{lc}
\hline Validation Parameter & Results \\
\hline System Suitability & \\
Theoretical Plates $(\mathrm{N})$ & 7088 \\
Linearity range $(\mathrm{mcg} / \mathrm{mL})$ & $10-200$ \\
Tailing factor & 1.1 \\
Retention time in minutes & 6.68 \\
LOD $(\mathrm{mcg} / \mathrm{mL})$ & 1.0 \\
LOQ $(\mathrm{mcg} / \mathrm{mL})$ & 10.0 \\
\hline
\end{tabular}

Limit of Detection (LOD) and Limit of Quantification (LOQ): The limit of detection (LOD) and limit of quantification (LOQ) for Nelfinavir Mesylate were found to be 1.0 and $10.0 \mu \mathrm{g} / \mathrm{mL}$ respectively. The signal to noise ratio is 3 for LOD and 10 for LOQ. 
From the typical chromatogram of Nelfinavir Mesylate as shown in Figure 1, it was found that the retention time was $6.68 \mathrm{~min}$. A mixture of acetonitrile and $\mathrm{pH}$ buffer 6 in a ratio of 90:10 v/v was found to be most suitable to obtain a peak well defined and free from tailing. In the present developed HPLC method, the standard and sample preparation required less time and no tedious extraction were involved. A good linear relationship $(\mathrm{r}=0.9999)$ was observed between the concentration range of $1.0-20.0 \mathrm{mcg} / \mathrm{mL}$. The assay of Nelfinavir Mesylate tablets was found to be $99.77 \%$. From the recovery studies it was found that about $99.92 \%$ of Nelfinavir Mesylate was recovered which indicates high accuracy of the method. The absence of additional peaks in the chromatogram indicates non-interference of the common excipients used in the tablets. This demonstrates that the developed HPLC method is simple, linear, accurate, sensitive and reproducible. Thus, the developed method can be easily used for the routine quality control of bulk and tablet dosage form of Nelfinavir Mesylate within a short analysis time.

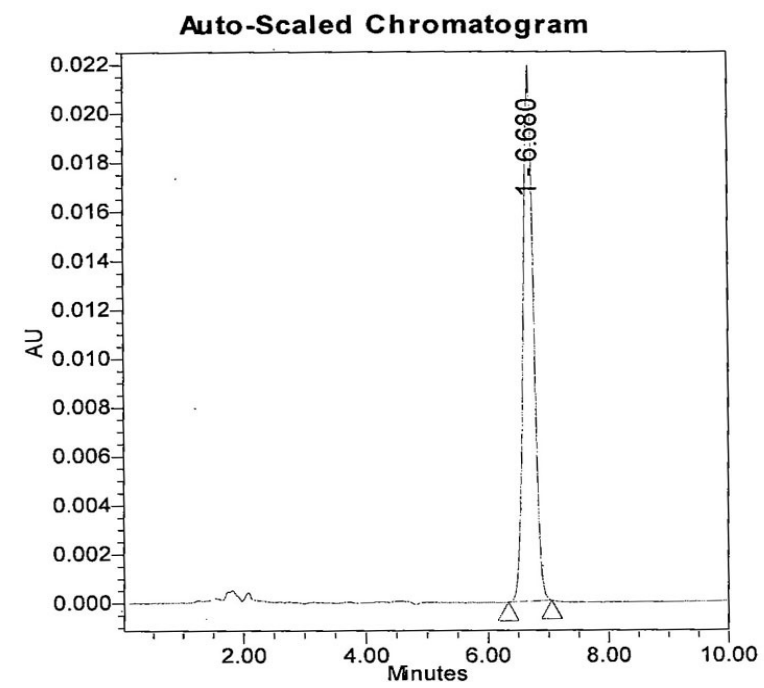

Figure 1. Typical Chromatogram of Nelfinavir Mesylate by HPLC

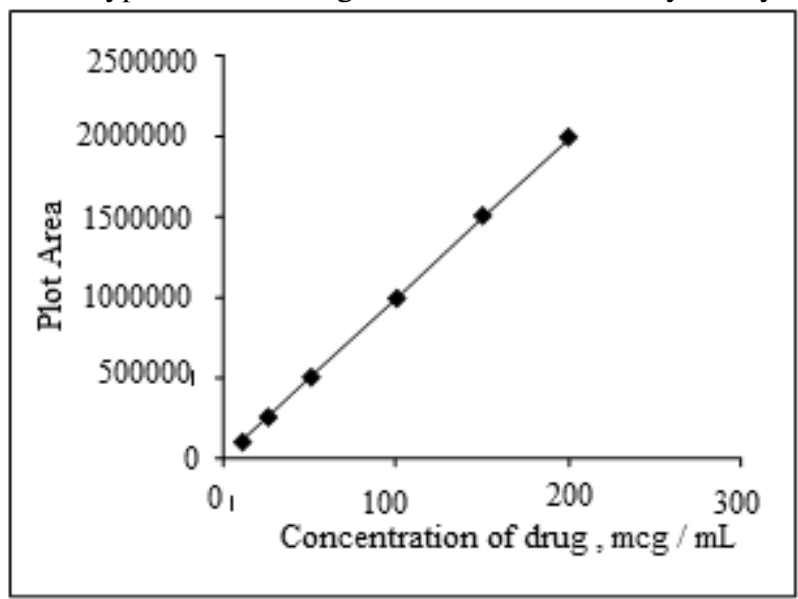

Figure 2. Calibration curve of Nelfinvir Mesylate by HPLC 


\section{References}

1. The Merck Index, XIII Ed., 2001,Merck Research Laboratories, (Monograph No: 6471) p 1154.

2. Sean C Sweetman, Martindale-The Complete Drug Reference, $34^{\text {th }}$ Ed., 2005 p 650.

3. Ellen Y Wu, James M Wilkinson, Danel G Naret, Valerie L Daniels, Linda Jefferson Williams, Deborah A Khalil, and Bhasker V Shetty, J.Chromatogr.B, 1997,695, 373.

4. Van Heeswijk R P G, Hoetelmans R M W, R.Harns, Meenhorst P L, Mulder J W, Lange J M A, and Beijnen J H, J.Chromatogr.B, 1998,719, 159-168.

5. Aymard G Legrand M, and Trihereau N, Bdiquet, Chromatogr.B, 2000, 744, 227.

6. Verne A Simon, Mamadou D and Thiam, J.Chromatogr. A, 2001, 913, 447-453.

7. Paul Metz, Sue Kohlhepp J and Gilbert D N, J.Chromatogr.B, 2002,773,159

8. Michele L Turner, Kedria Reed-walker, Jennifer R King and Edward P Acosta, J.Chromatogr.B, 2003,784, 331-341.

9. Valerie A Frerichs and Robin Di Francesco, J.Chromatogr.B, 2003,787,393-403.

10. Katharina M Rentsch, J.Chromatogr.B, 2003, 788, 339-350.

11. Rao Seshagiri, Mohan Reddy V M, Tadi R S Rao and Isukapatla N, J. Anal. Chem, 2004, 59(6), 552-556.

12. Rao S V, Murali Mohan, Rama Subba Reddy T, Prasad Viplava U and Sastry C S P, J. Institution of Chemists; 2003, 75(2), 46.

13. Rao S V, Murali Mohan, Reddy, Rama Subba T, Prasad Viplva U and Sastry C S P, Asian J. Chem, 2003,15(2), 971-976.

14. Vanitha Prakash K. and Venkateswara Rao J, E-J.Chem., 2006, 3, 78. 


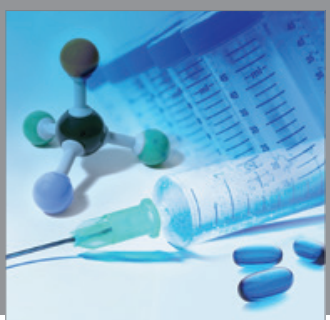

International Journal of

Medicinal Chemistry

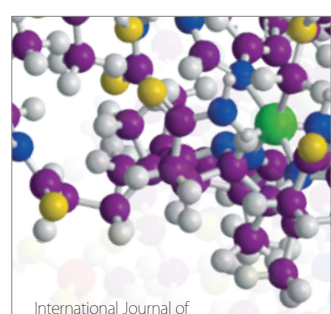

Carbohydrate Chemistry

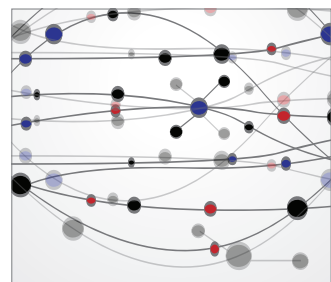

The Scientific World Journal
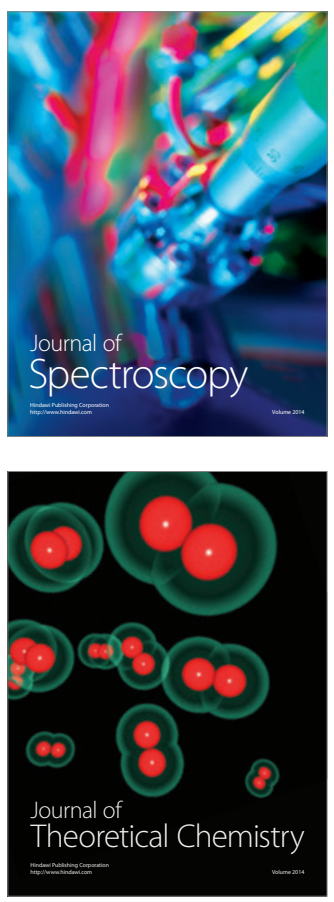
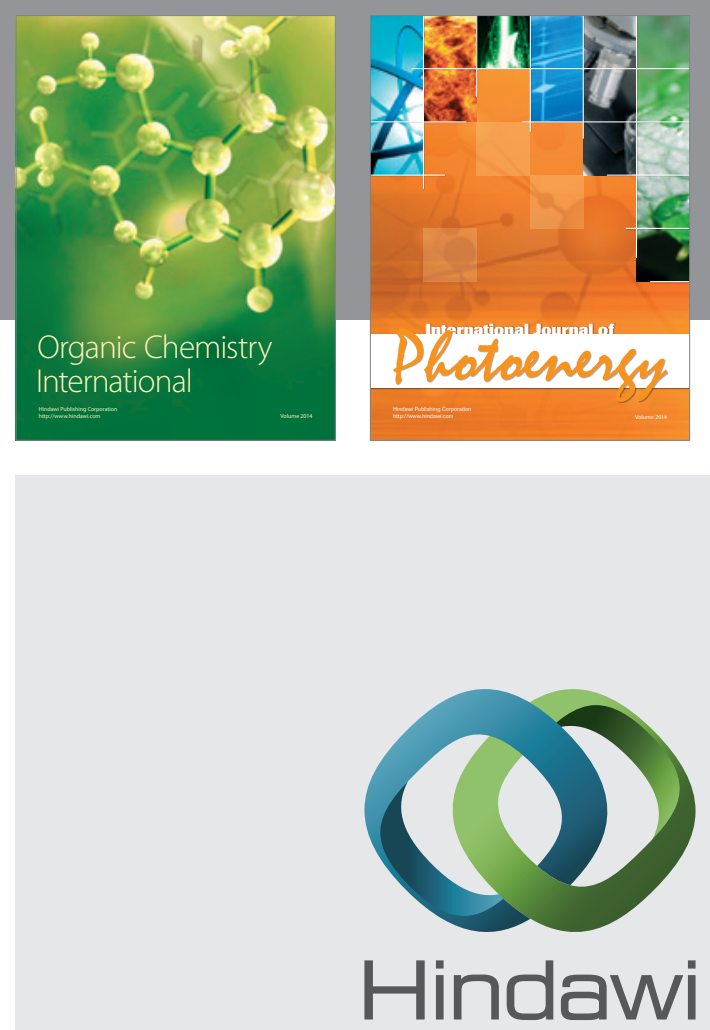

Submit your manuscripts at

http://www.hindawi.com
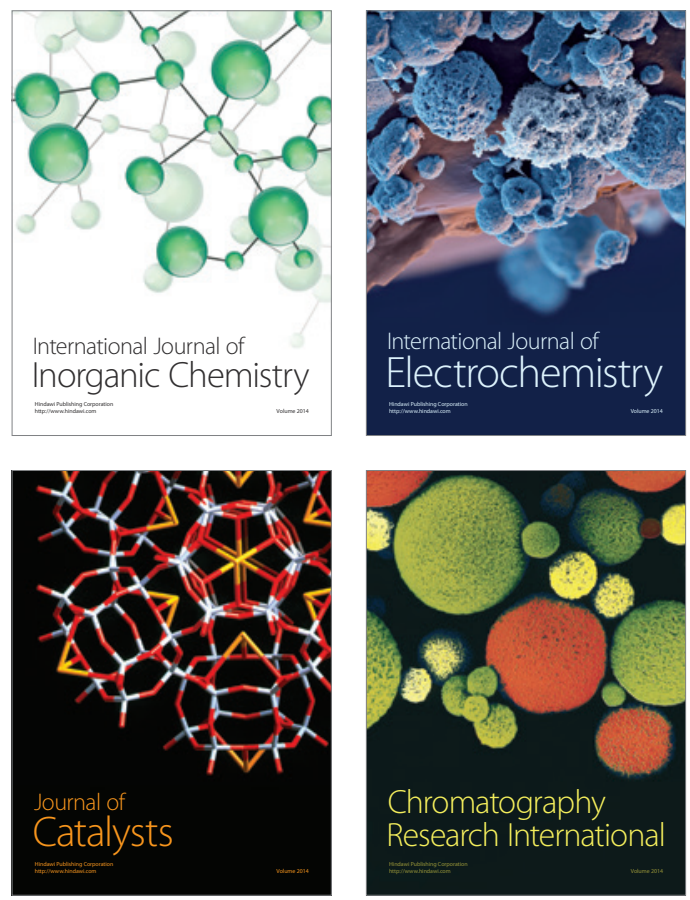
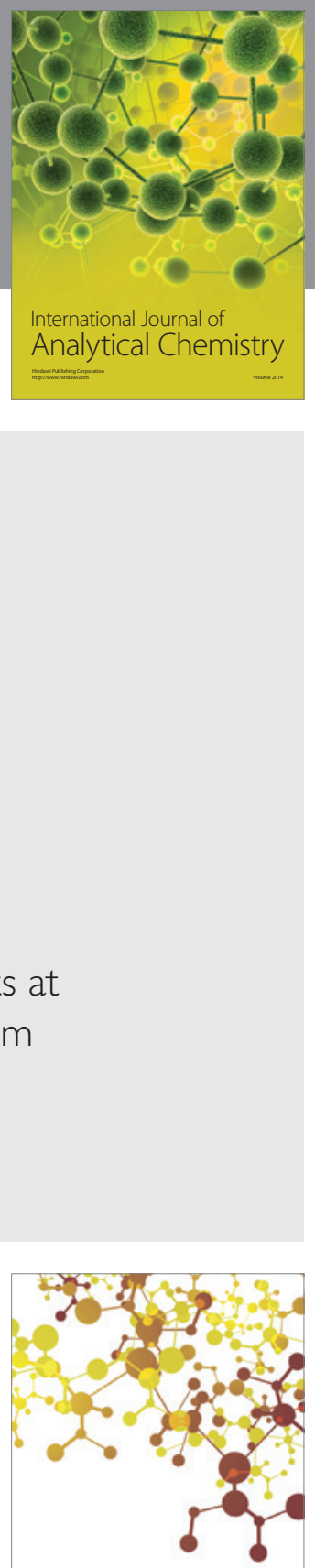

Journal of

Applied Chemistry
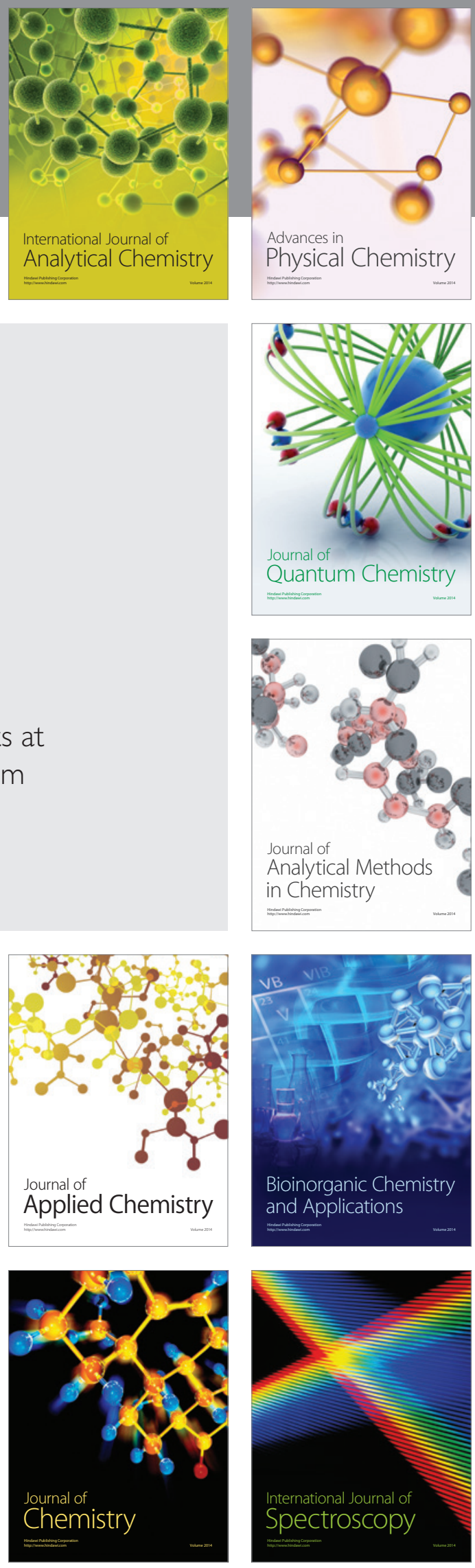